\title{
Relationship Between the Level of Pain and Quality of Sleep in Women After a Cesarean-section
}

\section{Sezaryen Sonrası Kadınlarda Ağrı Düzeyi ile Uyku Kalitesi Arasındaki iliş̧ki}

\author{
(iD Demet AKTAŞ1, iD Özlem İSKENDER², iD Mendize Gizem TOPALOĞLU2
}

${ }^{1}$ Çankırı Karatekin University Faculty of Health Science, Department of Midwifery, Çankırı, Turkey

${ }^{2}$ Hacettepe University Hospital, Nurse, Ankara, Turkey

\section{ABSTRACT}

Objective: The aim of this study was to examine the effect of the level of pain on quality of sleep in women after a cesarean section. This study was designed as a cross-sectional study.

Methods: The study was conducted in the obstetrics clinic of a university hospital in Ankara between May-July 2018. No sample selection was done, and the women who had underwent a cesarean section in the six-month period were included in the study. The study was conducted with 320 women. Visual Analogue scale was used to determine the level of pain and sufficiency level of sleep in the women. The Form of Factors that Affect Sleep Pattern (FFASP) was used for the purpose of determining early-stage sleep problems in the women.

Results: It was found in the our study that age, work status, and the type of the room (staying alone or with two or more patients) affected the severity of pain and sleep quality in women after a cesarean section. As the severity of pain in women who underwent a cesarean section increased, it was found that the FFASP scores increased and sleep quality decreased.

Conclusion: There is a relationship between the severity of pain in women after a cesarean section and the level of sleep sufficiency and quality.

Keywords: Cesarean section, level of pain, quality of sleep, women
ÖZ

Amaç: Bu çalışma, sezaryen sonrası hastanede yatan kadınların ağrı düzeyinin uyku kalitesine etkisini incelemek amaciyla kesitsel tipte dizayn edilmiştir.

Yöntemler: Çalışma Mayıs-Temmuz 2018 tarihleri arasında Ankara ilinde bulunan bir üniversite hastanesinin kadın hastalıkları ve doğum sonu servisinde yapılmıştır. Çalışmada, örneklem seçimine gidilmemiştir ve altı aylık sürede sezaryen operasyonu uygulanan kadınlar çalışmaya dahil edilmiştir. Araştırma, 320 kadın ile yürütülmüştür. Kadınların ağrı düzeylerini ve uyku yeterlilik düzeylerini belirlemek için görsel analog skala kullanılmıştır. Kadınların erken dönemde uyku sorununu belirlemek amacıyla Uyku Düzenini Etkileyen Etmenler Formu (UDEEF) kullanılmıştır.

Bulgular: Çalışmada sezaryen sonrası kadınların ağrı şiddeti ve uyku kalitesini yaş, çalışma durumu ve oda şeklinin etkilediği belirlenmiştir. Sezaryen uygulanan kadınların ağrı şiddeti artıkça UDEEF puan ortalamalarının arttığı, uyku düzen ve kalitelerinin azaldığı belirlenmiştir.

Sonuç: Sezaryen sonrası kadınların ağrı şiddeti ile uyku yeterliliği ve kalitesi arasında ilişki vardır.

Anahtar Sözcükler: Sezaryen, ağnı düzeyi, uyku kalitesi, kadınlar

Address for Correspondence: Demet AKTAŞ, Çankırı Karatekin University Faculty of Health Science, Department of Midwifery, Çankırı, Turkey

E-mail: daktas7706@gmail.com ORCID ID: orcid.org/0000-0003-1206-4004

Cite this article as: Aktaş D, İskender Ö, Topaloğlu MG. Relationship Between the Level of Pain and Quality of Sleep in Women After a Cesarean-section. Bezmialem Science 2020;8(1):62-7. 


\section{Introduction}

Pain control after a cesarean section carries a distinct importance in terms of the quality of patient care (1). The pain that develops after a cesarean section can prevent the mother from engaging with her baby under optimal conditions by negatively affecting the early-stage communication (breastfeeding, baby care etc.) $(1,2)$. However, the post-cesarean-section pain can lead to the development of problems in women such as irregular sleep pattern, constraint in physical activities (movement, etc.), increase in sensitivity to sounds and noises and inability to rest sufficiently due to anxiety and tiredness $(1,3)$. For this reason, effective control of pain in the period after a cesarean section carries great importance in terms of preventing problems that may develop, primarily in sleep patterns and the quality of sleep. Sleep is among the most fundamental daily activities of life and is necessary for an individual to meet physical, psychological, sociocultural, and intellectual needs. Sleep encompasses onethird of the lives of humans $(4,5)$. Accordingly, women meeting their needs for sleep in a balanced and adequate manner are able to maintain current level of health (6,7). However, pain that develops after surgical operations such as birth by cesarean section can lead to unfavorable outcomes in the pattern and quality of sleep due to care-treatment procedures, being in a foreign environment, inability to rest because of breastfeeding in 2-3 hour intervals, and inability to maintain daily routines (4). A previously conducted study determined that $45.5 \%$ of patients admitted to the hospital experienced a change in their patterns of sleep (4-8). Other studies reported that the total duration of sleep decreased by $80 \%$ in patients in the first night after surgical operations, that patients experienced sleep-related problems, and that the most important factor that caused sleep problems was pain $(8,9)$. The literature also reports that the deterioration in sleep patterns in patients triggers a decrease in pain tolerance and an increase in the severity of pain (10). For this reason, the effective evaluation of the pain scores of women after a cesarean, optimal and effective management of pain and impaired sleep patterns, the formation of the conditions necessary for adequate rest, and the maintenance of sleep quality should be among the nursing activities that must be handled with care. In the stage of creating a qualified nursing care plan for women after a cesarean section; the patient's expectations, perception of care, capacity to assess care, and satisfaction with the care should be considered $(8,10)$. Care and treatment beginning from the first day after a cesarean section should be adjusted based on the levels of pain and cycles of sleep/wakefulness. Pain should be taken under control, and foreign surroundings, voices, lights, and noises should be reduced. Infant care can interrupt the sleep of women and inhibit their sleeping while they are breastfeeding. In this stage, women should be supported in caring for infants while they are sleeping.

\section{Methods}

\section{Purpose and Type}

This study was designed as a cross-sectional study for the purpose of examining the effect of the level of pain on quality of sleep in women giving birth in the hospital after a cesarean section. The study was conducted in the obstetrician and maternity ward of the hospital of a university in Ankara between May and July 2018.

\section{Samples and Participants}

No sample selection was done, and women who had underwent a cesarean section in the six-month period were included in the study. The study was conducted with 320 women. The criteria for women to be included in the study were being above the age of 18 , agreeing to participate in the study and having no verbal communication problem.

\section{Data Collection Tools}

A 12-question data collection form containing some descriptive characteristics for women who underwent a cesarean section (age etc.) was used for the purpose of gathering data in the study. The researchers developed the data collection form after reviewing the literature, considering expert views $(4,6,10)$. The 10 centimeter $(\mathrm{cm})$ horizontal visual analogue scale (VAS) in pain was used for the purpose of determining the level of pain and sleep sufficiency inthe first and second day after the cesarean section in the women. The Form of Factors that Affect Sleep Pattern (FFASP) that aimed to evaluate the quantitative and qualitative quality of sleep in the mornings of the first and second days after the cesarean section was used for the purpose of determining early-stage sleep problems in the women (11). The highest score that can be received from the score is 120 and the lowest is 24 . The factors that affected the sleep of the patients such as pain, bed, light, heat, and sound, whether sufficient information was provided about the disease, and psychological factors such as level of anxiety were recorded in the FFASP. The Cronbach Alpha reliability coefficient for the FFASP was found to be 0.70 .

\section{Data Collection}

Women who would undergo a cesarean section were admitted to the hospital one night before the operation. The data collection form was subsequently administered to the women. The VAS was implemented to determine the hourly level of pain after the patient was readmitted to service following the cesarean section procedure on the day that the cesarean section operation was performed, and the average VAS score at the end of the day was recorded. The VAS was implemented for the evaluation of the sleep sufficiency at the earliest opportunity in the second morning after the cesarean section procedure and the FFASP was implemented to determine the pattern and quality of sleep. The VAS was implemented to determine again the level of pain and sleep sufficiency on the second day after the cesarean section. Also, all women after giving birth received postnatal care from the routine obstetricians and nurses. Postnatal care consisted of checking the state of consciousness and vital signs, assessing bleeding and uterus involution, assessing the patient with extreme pain in terms of hematoma (incision line), starting breastfeeding as soon as possible and helping the mother breastfeed her baby and providinge her with training on breastfeeding. 


\section{Ethical Dimension}

Institutional ethics committee approved the study, and written informed consents were obtained from the patients who agreed to participate in the study.

\section{Analysis of the Data}

The Statistical Package for Social Sciences (SPSS) version 22.0 was used for the analysis of data. Frequency, t-tests, Pearson correlation and ANOVA were used for the analysis.

\section{Results}

A total of 320 women monitored in the maternity ward after a cesarean section were included in the study. The mean age of the women was $30.6 \pm 5.5$ years. When the descriptive characteristics of the women were examined, it was determined that $62.4 \%$ had an educational level of high school and above, that $73.5 \%$ expressed their income level as "moderate", and that $62.8 \%$ were housewives. When the characteristics of the participants regarding sleep were examined, it was reported that $74.6 \%$ generally expressed their sleep patterns as "sufficient". Of the women included in the study, $48.7 \%$ were primipara and $67.2 \%$ were staying in rooms with two or more people (Table 1). All of the women were married, and it was determined that $27.9 \%$ had previously underwent a surgical procedure (cesarean section).

In the present study, while the mean of the VAS pain score on the first day after the cesarean section was found $6.97 \pm 2.4$, the mean of VAS pain score on the second day was found $4.70 \pm 2.17$. While the mean of the VAS sleep sufficiency score on the first day after the cesarean section was determined to be $5.12 \pm 2.68$, the mean of the VAS sleep sufficiency score on the second day was determined $5.48 \pm 2.39$ (Figure 1).
The mean of FFASP scores of the women was found to be $77.17 \pm 16.73$. When the FFASP scale was examined, it was determined that pain, medical devices attached to the body and the noisy environment were the factors that negatively affected the sleep patterns of the women after the cesarean section (Figure 2).

According to Table 1, in the current study, it was determined that the mean of FFASP and VAS pain scores of the women in the 18-30 age group were higher compared with that of those in the 31-44 age group, and the mean of VAS sleep sufficiency scores were lower $(\mathrm{p}<0.05)$. In our study that it was found the mean FFASP, VAS pain, and VAS sleep sufficiency scores of the women who worked were higher than those of the housewives

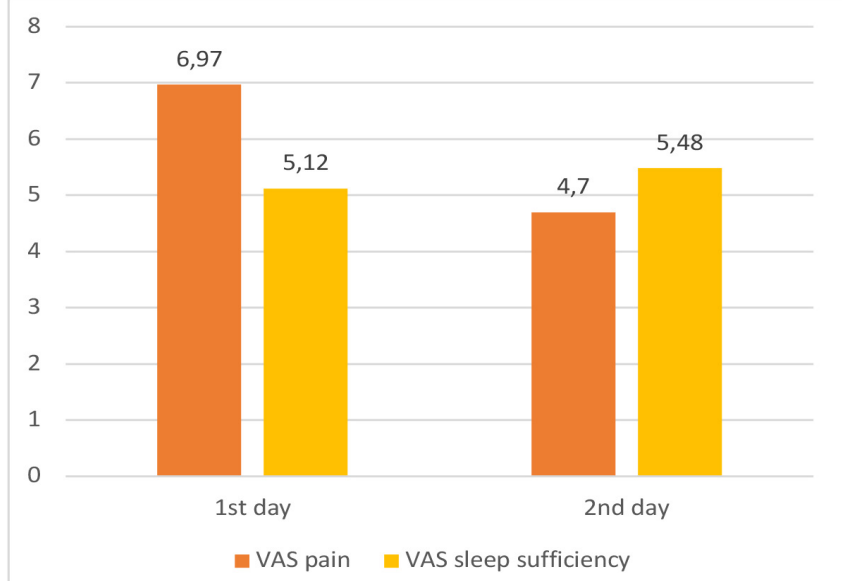

Figure 1. Relationship between VAS pain and VAS sleep sufficiency measurements

VAS: Visual analogue scale

Table 1. Distribution of form of factors that affect sleep pattern, visual analogue scale pain and visual analogue scale sleep sufficiency scores according to some descriptive features of women who had underwent a cesarean section $(n=320)$

\begin{tabular}{|c|c|c|c|c|c|c|c|c|c|c|c|}
\hline $\begin{array}{l}\text { Some } \\
\text { Characteristics }\end{array}$ & n (\%) & $\begin{array}{l}\text { FFASP } \\
\text { Mean } \pm \text { SD }\end{array}$ & $\mathrm{P}$ & $\begin{array}{l}\text { VAS pain } \\
1^{\text {st }} \text { day } \\
\text { Mean } \pm \text { SD }\end{array}$ & $\mathrm{P}$ & $\begin{array}{l}\text { VAS pain } \\
2^{\text {nd }} \text { day } \\
\text { Mean } \pm S D\end{array}$ & $\mathrm{p}$ & $\begin{array}{l}\text { VAS sleep } \\
\text { sufficiency } \\
1^{\text {st }} \text { day } \\
\text { Mean } \pm \text { SD }\end{array}$ & $\mathrm{P}$ & $\begin{array}{l}\text { VAS sleep } \\
\text { sufficiency } \\
2^{\text {nd }} \text { day } \\
\text { Mean } \pm \text { SD }\end{array}$ & $\mathrm{P}$ \\
\hline $18-30$ & $160(50.0)$ & $85.35 \pm 16.94$ & \multirow[t]{2}{*}{0.042} & $7.01 \pm 2.42$ & \multirow[t]{2}{*}{0.001} & $4.98 \pm 2.19$ & \multirow[t]{2}{*}{0.005} & $4.77 \pm 2.47$ & \multirow[t]{2}{*}{0.021} & $5.34 \pm 2.46$ & \multirow[t]{2}{*}{0.003} \\
\hline $31-44$ & $160(50.0)$ & $78.98 \pm 16.97$ & & $6.93 \pm 2.38$ & & $4.51 \pm 2.14$ & & $5.46 \pm 2.84$ & & $5.99 \pm 2.78$ & \\
\hline \multicolumn{12}{|l|}{ Working status } \\
\hline Laboring & $119(37.2)$ & $81.91 \pm 14.83$ & \multirow[t]{2}{*}{0.001} & $7.20 \pm 2.32$ & \multirow[t]{2}{*}{0.043} & $4.99 \pm 2.20$ & \multirow[t]{2}{*}{0.025} & $5.30 \pm 2.70$ & \multirow[t]{2}{*}{0.002} & $5.80 \pm 2.41$ & \multirow[t]{2}{*}{0.001} \\
\hline Housewives & $201(62.8)$ & $74.36 \pm 17.19$ & & $6.84 \pm 2.44$ & & $4.53 \pm 2.13$ & & $4.81 \pm 2.62$ & & $4.96 \pm 2.78$ & \\
\hline \multicolumn{12}{|c|}{ Effect of pain on sleep quality within the last 24 hours } \\
\hline Yes & $171(53.4)$ & $79.01 \pm 15.50$ & 0.014 & $7.78 \pm 2.19$ & 0.019 & $5.26 \pm 1.99$ & 0.049 & $5.08 \pm 2.70$ & 0.001 & $5.37 \pm 2.31$ & 0.037 \\
\hline $\begin{array}{l}\text { Room where } \\
\text { two or more } \\
\text { people staying }\end{array}$ & $199(67.2)$ & $84.17 \pm 16.44$ & & $7.36 \pm 2.06$ & & $4.93 \pm 2.02$ & & $4.73 \pm 2.63$ & & $5.13 \pm 2.53$ & \\
\hline
\end{tabular}

VAS: Visual Analogue scale, FFASP: Form of Factors that Affect Sleep Pattern, SD: Statistical deviation, p: Statistical analysis 
$(p<0.05)$. In the present study, it was determined that the mean FFASP and VAS pain scores of women who stated that the status of pain in the previous 24 hours affected their sleep patterns were higher compared with those of the women who stated that it did not and the mean VAS sleep sufficiency score was lower $(p<0.05)$. It was found in our study that the mean FFASP and VAS pain scores of women staying in single-person private rooms were lower compared with women staying in rooms with two or more people and that the average VAS sleep sufficiency score was higher $(\mathrm{p}<0.05)$.

In our study, a highly negative correlation was found between the the mean of VAS pain and the mean of VAS sleep sufficiency scores on the first day following the cesarean section $(r=-0.730$; $\mathrm{p}=0.001$ ) and a highly positive correlation was found between the mean of VAS pain scores and the mean of FFASP scores on the first day following the cesarean section $(r=-0.872 ; p=0.001)$, and these correlations were statistically significant. A moderately negative correlation was found between the the mean of VAS pain and the mean of VAS sleep sufficiency on the second day following the cesarean section $(\mathrm{r}=-0.440 ; \mathrm{p}=0.001)$, and a highly positive correlation was found between the the mean of VAS pain and the mean of FFASP on the second day following the cesarean section $(r=0.682 ; p=0.001)$, and these correlations were statistically significant. Based on our data, as the levels of pain of the women who underwent a cesarean section increased, the mean of FFASP scores increased, and sleep sufficiency decreased (Table 2, Figure 1).

\section{Discussion}

Many women (50-70\%) experience severe or moderate pain after a cesarean section $(9,12-14)$. Of women, $40 \%$ report that they experience standard pain after a cesarean section at moderate or severe levels while resting despite treatment (15-18). We found that women experienced severe pain on the first day after the cesarean section, and it was observed that the pain gradually subsided. We found that the sleep insufficiency of women on the first day after the cesarean section decreased considerably and, although not much, sleep sufficiency partially increased on the second day. The mean FFASP scores of women in our study were

Table 2. The correlation between the mean scores of visual analogue scale pain, visual analogue scale sleep sufficiency and form of factors that affect sleep pattern of women $(n=320)$

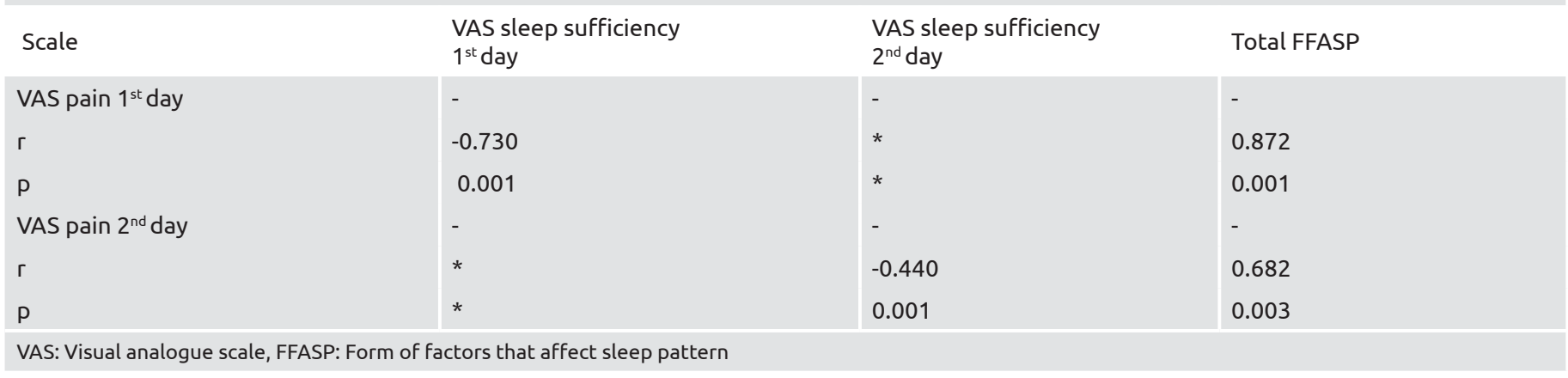

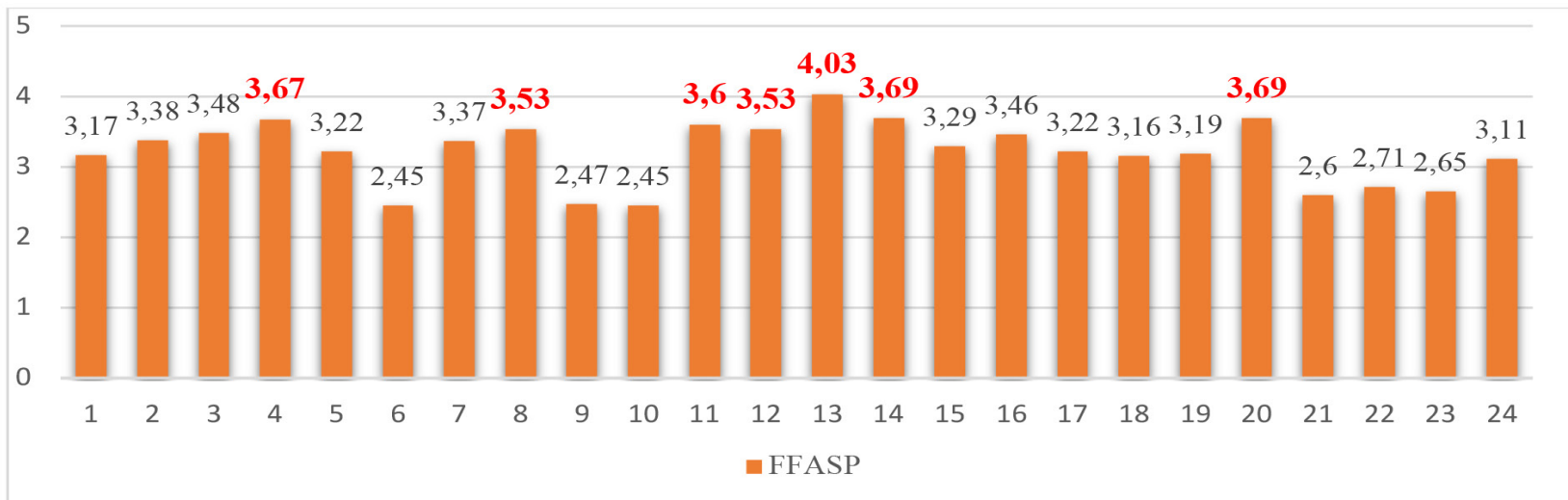

Figure 2. Distribution of factors affecting sleep patterns of women

1. The bed is uncomfortable, 2 . The pillow is uncomfortable, 3. Bedding is dirty and uneven, 4 . The room is airless, 5 . There is much light in the room, 6 . The room is dark, 7. The temperature of the room is inappropriate, 8 . The room is crowded, 9 . Being alone in the room, 10. Having a companion beside her, 11. Entering and exiting the room frequently, 12. Interventions made during sleep time, 13 . Having pain, 14. Medical devices fitted to the body, 15. Being hungry or satiated, 16. Having concerns about the disease, 17. Not having enough information about the disease, 18. Thinking of home or work, 19. Not feeling safe, 20. Noise in the surrounding area, 21. Inability to exercise and sport, 22. No activity to do during the day, 23. Inability to apply pre-sleep habits, 24 . Hours of sleeping and waking up in the hospital.

FFASP: Form of factors that affect sleep pattern 
also found to be high. In the study that Yilmaz et al. (2008) conducted, the mean FFASP scores of the women was found to be high (17). Our study found that the sleep insufficiency based on severe pain of women on the first day after the cesarean section decreased and, together with the decrease of pain, sleep sufficiency partially increased on the second day. We found that the presence of medical devices attached to the body affected the quality of sleep apart from pain. Previously conducted studies reported that medical devices attached to the body led to pain and position constraint in patients and that these problems led to difficulty in sleeping and deterioration of sleep quality in $16.8 \%$ of patients $(2,13,14)$. It was reported that age possessed a strong influence in the threshold of pain perception (19). We found that the pain levels on the first and second days following the cesarean section of women in the 18-30 age group were quite a bit higher than those of women in the 31-44 age group, that women did not get enough sleep, and that their sleep patterns deteriorated $(p<0.005)$. Beebe and Lee (15) reported in their study that the birth rate by cesarean section in young women who experienced sleep problems was higher, that the pain they experienced after the cesarean section was higher, and that their quality of sleep decreased as the severity of pain increased. Our study determined that the severity of the pain in working women compared with housewives was higher on first and second days after the cesarean section and that their sleep sufficiency and sleep patterns deteriorated in relation to this $(\mathrm{p}<0.05)$. It was reported in the literature that the expectations regarding pain, experiences, perceptions of pain, and capacities to assess the effectiveness of the performed procedure of women who worked and who had high levels of education were influential in expressing their problems $(13,20,21)$. In the present study we found the mean score of pain severity to be higher and sleep sufficiency to be lower in women who stated that their pain problems in the past 24 hours affected their sleep pattern on first and second days after the cesarean section than in the women who stated that it did not $(\mathrm{p}<0.05)$. Özkaya et al. (22) (2013) determined in their study that the pain affected the sleep patterns of the patients mostly on the first day after the surgery. Our study detected that the severity of pain in the women staying in rooms with two or more people increased, that the sleep sufficiency based on the pain decreased, and that their sleep patterns significantly deteriorated. The excessive number of patients in the room leads to triggering of the pain and the patients are unable to sleep comfortably at night $(5,7,12,19)$. According to the results of the analysis for the correlation between the VAS pain, VAS sleep insufficiency and FFASP scale in our study, it determined that as the severity of pain after a cesarean section increased, sleep sufficiency and sleep quality decreased. A highly negative relationship was found between the severity of pain and the sleep sufficiency and sleep quality of women after a cesarean section.

\section{Study Limitations}

This study was conducted in a small group of women in one hospital. The results were interpreted according to the patients' self-reports. Therefore, the results of this study cannot be generalized.

\section{Conclusion}

It was found in our study that age, work status, status of pain in the previous 24 hours affecting sleep, and the type of the room (staying alone or with two or more patients) affected the severity of pain, sleep insufficiency, and sleep pattern and quality in women after a cesarean section. As the severity of pain in women who underwent a cesarean section increased, it was found that the mean of FFASP scores increased and sleep quality decreased. There was a relationship between the severity of pain in women after a cesarean section and the level of sleep sufficiency and sleep pattern and quality. Based on this data, the effective control of pain after a cesarean section carries great importance in terms of better quality of sleep for the patient.

Acknowledgments: The authors would like to thank the women who so willingly participated in this study.

\section{Ethics}

Ethics Committee Approval: The necessary permissions were obtained from the hospital where the research and from the Ufuk University Social and Humanities Scientific Research and Publication Ethics Committee (protocol number: 2017/35).

Informed Consent: Consent form was filled out by all participants.

Peer-review: Externally and internally peer-reviewed.

\section{Authorship Contributions}

Concept: D.A., Ö.İ., M.G.T., Design: D.A., Ö.İ., M.G.T., Data Collection or Processing: D.A., Ö.İ., M.G.T., Analysis or Interpretation: D.A., Ö.İ., M.G.T., Literature Search: D.A., Ö.İ., M.G.T., Writing: D.A., Ö.İ., M.G.T.

Conflict of Interest: No conflict of interest was declared by the authors.

Financial Disclosure: The authors declared that this study received no financial support.

\section{References}

1. Hüseyinoğlu Ü, Ülker K, Temur İ, Kütük M. Comparison of meperidine and tramadol in postoperative pain management following elective cesarean births: A prospective randomized study. Kafkas J Med Sci 2011;1:53-6.

2. Baş NG, Karatay G, Bozoğlu Ö, Akay M, Kunduracı E, Aybek H. Postoperative pain management: nursing practices. J Hacettepe Uni Faculty of Nurs 2016;3:40-9.

3. Kilıçaslan A, Tuncer S, Yüceaktaş A. The effects of intravenous paracetamol on postoperative analgesia and tramadol consumption in cesarean operations. Agri 2010;22:7-12.

4. Cunningham JM, Blake C, Power CK, O’Keeffe D, Kelly V, Horan $S$. The impact on sleep of a multidisciplinary cognitive behavioural pain management programme: a pilot study. BMC Musculoskelet Disord 2011;12:5.

5. Gögenur I. Postoperative circadian disturbances. DMJ 2010;57:1-20. 
6. Köybaşı EŞ, Oskay ÜY. Effects of pregnancy process on the quality of sleep. Gülhane Med J 2017;59:1-5.

7. Liao WC, Huang CY, Huang TY. A systematic review of sleep patterns and factors that disturb sleep after heart surgery. JNHR 2011;19:275-88.

8. Çoban A, Yanıkkerem UE. Sleep quality and fatigue in pregnant women. Ege Med J 2010;49:87-94.

9. Joshi GP, Kehlet H. Procedure specific pain management: The road to improve postsurgical pain management? Anesthesiology 2013;118:780-82.

10. Yıldırım G, Ertekin PŞ, Düger C, Altıparmak S, Gürsoy S, Mimaroğlu C. The relation between pain perceived by the patients hospitalized in the algology clinic and their sleep and quality of life. Pain 2015;27:89-96.

11. Tosunoğlu A. Examination of the factors affecting the sleep requirements of hospitalized adult patients. Master Thesis, Ege University Institute of Health Sciences, Izmir.1997.

12. Francis L, Fitzpatrich JJ. Postoperative pain: Nurses' knowledge and patients' experiences. ASPMN 2013;14:351-57.

13. Kainu JP, Sarvela J, Tiippana E, Halmesma"ki E, \& Korttila KT. Persistent pain after caesarean section and vaginal birth: a cohort study. Int J Obstet Anesth 2010;19:4-9.

14. Savoia G, Alampi D, Amantea B. Postoperative pain treatment SIAARTI Recommendations 2010. Short version. Minerva Anestesiol 2010;76:657-67.
15. Beebe KR, Lee KA. (2007). Sleep disturbance in late pregnancy and early labor. JPNN 2007;21:103-8.

16. Büyükyılmaz FE, Sendir M, Acaroğlu R. Evaluation of night-time pain characteristics and quality of sleep in postoperative Turkish orthopedic patients. Clin Nurs Res 2011;20:326- 42.

17. Yılmaz E, Kutlu AK, Çeçen D. The factors those affect sleeping status of the patients hospitalized in surgical clinics. New Med J 2008;25:149-56.

18. Yüksel BA, Seven A, Yıldız Y, Gözükara İ, Kucur SK, Polat M. Evaluation of the factors affecting pain perception of the patients before and after vaginal and cesarean delivery. Turk J Clin Lab 20156:116-20.

19. Kamysheva E, Skouteris H, Wertheim EH, Paxton SJ, Milgrom J. A prospective investigation of the relationships among sleep quality, physical symptoms, and depressive symptoms during pregnancy. J Affect Disord 2010;123:317-20.

20. Eisenach JC, Pan P, Smiley RM, Lavand'homme P, Landau R, Houle TT. Resolution of pain after childbirth. Anesthesiology 2013;118:143-51.

21. Ölçer Z, Bozkurt G. The effect of sleep quality to the labor and labor pain. HSP 2015;2:334-44.

22. Özkaya BÖ, Yücez Gönenç M, Gül A, Alış H. Factors affecting the sleep patterns of hospitalized patients during the early postoperational period. Bakırköy Med J 2013;9:121-5. 